Brit. J. industr. Med., 1949, 6, 100.

\title{
SICKNESS ABSENCE DUE TO PEPTIC ULCERS
}

\author{
BY
}

\author{
RICHARD DOLL* and M. M. BUCKATSZCH*
}

From the Dietetic Department, Central Middlesex Hospital

(RECEIVED FOR PUBLICATION, SEPTEMBER 17, 1948)

According to an estimate made by Avery Jones and Pollak (1945), 1,500,000 men and women in England and Wales suffer from peptic ulcer, and Bockus (1943) expressed the general opinion when he said that "Well over 10 per cent. of all adults of the male sex have or have had an ulcer." It is therefore of considerable interest to determine the significance of peptic ulcer to industry, in terms of sickness absence.

During a survey undertaken to study occupational factors in the rtiology of peptic ulcer, it was possible to determine the sickness experience of a number of men with peptic ulcers and to compare it with the experience of men of the same age employed in the same occupation. All the men employed in a number of firms were interviewed by a social worker and particulars of their occupations were recorded, together with any symptoms of dyspepsia. Men who had had a peptic ulcer or who had symptoms of major dyspepsia were referred for a medical interview. They were accepted as having had a peptic ulcer only if a radiological or operative diagnosis had been made at hospital or if they had had a frank hæmatemesis ; in addition, a small number were diagnosed radiologically in the course of the survey. Confirmation of the diagnosis was obtained directly from the hospital or doctor concerned in 77 per cent. of the cases, but when no medical evidence could be obtained (due to lack of records etc.) the men's statements were accepted. It is unlikely that this can have introduced much error as, when medical evidence was available, it conflicted with the men's statements in only 6 per cent. of the cases.

\section{Method Adopted in the Present Study}

The sickness absence of men with peptic ulcers was obtained from the firms' records for 1946 and, when the information was available at the time of the investigation, also for 1947.

Controls were chosen at random from the records

* Working with a grant from the Medical Research Council. of the survey from among men free from dyspepsia, of the same age, employed in the same occupation, and on the same type of shift. Whenever possible controls of exactly the same age were selected but, when they were not available, men whose age varied by four years or less from the corresponding ulcer cases were accepted. When no suitable control was available the ulcer case was omitted from the investigation. Altogether, records of 119 pairs were available, 96 for 1946, and 23 for both 1946 and 1947, making a total of 284 years' experience.

The material was collected from seven firms, six of which were in London while the other was in a small southern provincial town. The types of industry concerned and the occupations of the men are shown in Table 1.

The occupations of the controls were identical with those of the ulcer subjects and they have therefore been omitted from the Table. The recorded occupations are the occupations in which the subjects were employed at the time of the survey; changes in the course of the year have not been allowed for.

When a man was not employed by the firm for the whole year, an estimate of the annual absence was made from the experience of that part of the year for which he was employed. Little error can have been introduced by this as it applied to only 17 of the 284 man-years.

\section{Findings}

Sickness absence was measured in working days lost. The experience of the two groups of ulcer subjects and controls is summarized in Table 2.

From Table 2 it appears that when the subjects are divided into two groups, according to whether they had less or more than ten days' sickness a year, there is a significant difference between the ulcer subjects and the controls. This is confirmed when the sickness absence of each individual ulcer subject is compared directly with the sickness absence of the corresponding control. The results are shown in Table 3. 
TABLE 1

OCCUPATIONAL DISTRIBUTION OF ULCER SUBJECTS

\begin{tabular}{|c|c|c|c|c|c|c|c|c|c|c|c|}
\hline \multirow[b]{2}{*}{$\begin{array}{l}\text { Social } \\
\text { class }\end{array}$} & \multirow{2}{*}{\multicolumn{3}{|c|}{ Occupation }} & \multicolumn{7}{|c|}{ Type of industry } & \multirow[b]{2}{*}{$\begin{array}{c}\text { Total } \\
\text { number } \\
\text { of men }\end{array}$} \\
\hline & & & & $\begin{array}{c}\text { Elec- } \\
\text { trical } \\
\text { research } \\
\text { labora- } \\
\text { tories }\end{array}$ & $\begin{array}{c}\text { Civil } \\
\text { Service }\end{array}$ & $\begin{array}{c}\text { Dynamo } \\
\text { manu- } \\
\text { facture }\end{array}$ & $\begin{array}{c}\text { Glass } \\
\text { manu- } \\
\text { facture }\end{array}$ & $\begin{array}{c}\text { Goods } \\
\text { trans- } \\
\text { port }\end{array}$ & $\begin{array}{c}\text { Pas- } \\
\text { senger } \\
\text { trans- } \\
\text { port }\end{array}$ & $\begin{array}{c}\text { Food } \\
\text { pre- } \\
\text { paration }\end{array}$ & \\
\hline \multirow{2}{*}{1 and 2} & Professional & $\cdots$ & $\cdots$ & 5 & 5 & - & - & 一 & - & - & \multirow{15}{*}{$\begin{array}{r}10 \\
4 \\
2 \\
15 \\
14 \\
4 \\
13 \\
2 \\
4 \\
5 \\
12 \\
4 \\
12 \\
7 \\
11\end{array}$} \\
\hline & Foremen .. & .. & .. & - & - & 一 & - & 2 & 2 & - & \\
\hline ," & Electricians. . & .. & & - & - & 2 & - & 二 & - & 一 & \\
\hline 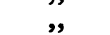 & Mechanics an & ooln & ers & 2 & - & 8 & 3 & - & 2 & - & \\
\hline ", & Motor drivers & .. & $\ldots$ & - & - & - & - & 2 & $1 \overline{2}$ & 一 & \\
\hline ", & Cooks & & $\ldots$ & - & - & - & - & - & - & 4 & \\
\hline 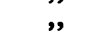 & Clerks and sto & nen & . & 1 & 3 & 3 & 1 & 5 & - & - & \\
\hline ," & Other skilled & ker & $\ldots$ & 1 & - & - & - & - & 1 & - & \\
\hline 4 & Bus conductor & .. & & - & - & - & - & - & 4 & - & \\
\hline , & Horse vehicle & vers & & - & - & - & - & 5 & 一 & - & \\
\hline 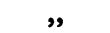 & Machine hand & $\mathrm{mi}$ & led & - & 一 & - & 8 & - & - & 4 & \\
\hline \multirow{2}{*}{ ’’ } & Packers $\quad \ldots$ & .. & .. & - & 一 & 1 & 2 & 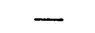 & - & 1 & \\
\hline & Porters & .. & .. & - & - & - & - & 12 & - & - & \\
\hline , & Messengers & .. & . & - & 7 & - & - & - & 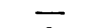 & 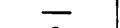 & \\
\hline \multirow[t]{2}{*}{, } & Labourers .. & 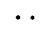 & $\cdots$ & 一 & - & 1 & 4 & 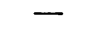 & 3 & 3 & \\
\hline & Total & .. & $\ldots$ & 9 & 15 & 15 & 18 & 26 & 24 & 12 & 119 \\
\hline
\end{tabular}

From Table 3 it appears that the average sickness absence of men with proved peptic ulcers is 6.0 working days a year more than that of comparable controls without dyspepsia.

The excess sickness absence was practically the same whether the ulcer was gastric or duodenal and whether the man was under or over 45 . The results are shown in Table 4 but, in view of the large size of the standard errors, it is not desired to attach much significance to them.

\section{Discussion}

In the seven firms included in the investigation a total of 155 proved ulcers were diagnosed among 2,871 men, giving an incidence of 5.4 per cent. A mean of 6.0 days' excess sickness absence in peptic ulcer subjects therefore indicated an annual absence of 32.4 working days per hundred men which could be attributed directly or indirectly to peptic ulcer. In addition, a number of men in whom the diagnosis

TABLE 2*

ANNUAL SICKNESS ABSENCE

\begin{tabular}{|c|c|c|c|c|c|c|c|c|c|c|}
\hline \multirow{2}{*}{ Class of men } & & \multicolumn{7}{|c|}{ Number of Men } & \multirow{2}{*}{\multicolumn{2}{|c|}{$\begin{array}{c}\text { Working days } \\
\text { lost }\end{array}$}} \\
\hline & & \multicolumn{7}{|c|}{ Working days lost } & & \\
\hline \multirow{3}{*}{$\begin{array}{l}\text { Ulcer subjects .. } \\
\text { Controls }\end{array}$} & & $0-$ & $1-$ & $10-$ & $20-$ & $50+$ & $0-$ & $10+$ & Mean & $\begin{array}{l}\text { Standard } \\
\text { error }\end{array}$ \\
\hline & $\begin{array}{l}\ldots \\
\ldots\end{array}$ & $\begin{array}{l}39 \\
47\end{array}$ & $\begin{array}{l}43 \\
52\end{array}$ & $\begin{array}{l}26 \\
21\end{array}$ & $\begin{array}{l}21 \\
17\end{array}$ & $\begin{array}{r}13 \\
5\end{array}$ & $\begin{array}{l}82 \\
99\end{array}$ & $\begin{array}{l}60 \\
43\end{array}$ & $\begin{array}{l}16 \cdot 37 \\
10 \cdot 32\end{array}$ & $\begin{array}{l}2.17 \\
1.55\end{array}$ \\
\hline & & \multicolumn{5}{|c|}{$\begin{array}{l}\chi^{2}=6.16 \\
n=4 \\
10<P<0.20\end{array}$} & \multicolumn{2}{|c|}{$\begin{array}{l}\chi^{2}=4.40 \\
\mathrm{n}=1 \\
0.02<P<0.05\end{array}$} & & · \\
\hline
\end{tabular}

* The inclusion of the sickness absence of 23 men for two years, counting each year's experience as a separate observation, is open to theoretical statistical objections. For if a man's sickness absence in one year is correlated with his sickness absence in another, the observation of a second year's experience would not increase the statistical significance of the comparisons between men in the same way as would fresh observations in different men. In this instance the objection is not of practical importance as the correlations between the experiences of 1946 and 1947 are low :

Sickness absence of ulcer subjects, $r=0.076$

," ," controls, $r=-0.110$

fence between sickness absence

None of these correlation coefficients are significant $(P>0.05)$. 
TABLE 3*

DIFFERENCE BETWEEN SICKNESS ABSENCE OF ULCER SUBJECTS AND CONTROLS

\begin{tabular}{c|c|c|c}
\hline $\begin{array}{c}\text { No. of } \\
\text { pairs } \\
(n+1)\end{array}$ & $\begin{array}{c}\text { Total } \\
\text { difference } \\
\text { (days) } \\
S(x)\end{array}$ & $\begin{array}{c}\text { Mean } \\
\text { difference } \\
\left(\begin{array}{c}\text { days }) \\
\bar{x}=\end{array}\right.\end{array}$ & $\begin{array}{c}\text { Sum of } \\
\text { squares } \\
S(x) / n+1\end{array}$ \\
\hline 142 & 859 & 6.05 & 158,273 \\
\hline
\end{tabular}

Variance, $\sigma^{2},=1085.6500 \mathrm{t}=\overline{\mathrm{x}} / \frac{\sigma}{\sqrt{\mathrm{n}+1}}=2 \cdot 20$

Standard error

of mean $=2.75 \mathrm{n}=141,0.02<\mathrm{P}<0.05$

- See footnote to Table 2 .

was not proved had symptoms suggestive of peptic ulcer, so that the total sickness absence from this cause was probably appreciably greater.

The most closely comparable figures are provided by the Reports on Incapacitating Sickness issued by the Department of Health for Scotland. For the year 1936-37 these showed a loss of 33.3 working days per hundred men from peptic ulcer (Department of Health for Scotland, 1939). The Scottish figures are based on insurance certificates and are, therefore, not strictly comparable. It is probable that a proportion of the absence due to peptic ulcer is attributed to such general conditions as gastritis or dyspepsia. Nevertheless, the two figures are of the same order of magnitude and their similarity confirms the general validity of the findings.

This large amount of sickness due to one condition provides a serious challenge both to medicine and industry. It is evident that 5 per cent. of the male working population, who can make a substantial contribution to the national effort, cannot be excluded from ordinary employment, quite apart from

TABLE 4*

EFFECT OF SITE OF THE ULCER AND OF AGE

\begin{tabular}{|c|c|c|c|}
\hline $\begin{array}{l}\text { Type of } \\
\text { ulcer }\end{array}$ & $\begin{array}{l}\text { No. of } \\
\text { men }\end{array}$ & $\begin{array}{c}\text { Mean excess } \\
\text { sickness absence } \\
\text { compared with } \\
\text { controls } \\
\text { (days) }\end{array}$ & $\begin{array}{l}\text { Standard } \\
\text { error of } \\
\text { mean (days) }\end{array}$ \\
\hline $\begin{array}{l}\text { Gastrict } \\
\text { Duodenalt } \\
\text { Age under } 45 \\
\text { Age over } 45\end{array}$ & $\begin{array}{l}47 \\
81 \\
51 \\
91\end{array}$ & $\begin{array}{l}5 \cdot 7 \\
7 \cdot 5 \\
5 \cdot 8 \\
6 \cdot 2\end{array}$ & $\begin{array}{l}6 \cdot 58 \\
2 \cdot 50 \\
4 \cdot 10 \\
3 \cdot 67\end{array}$ \\
\hline \multicolumn{4}{|c|}{$\begin{array}{l}\text { * See footnote to Table } 2 \text {. } \\
\text { The sum of the numbers of men with gastric and duodenal ulcers } \\
\text { is less than } 142 \text { as the site of the ulcer was not known in a few } \\
\text { instances. } \\
\ddagger \text { The actual figures are } 38 \cdot 8 \text { days lost due to peptic ulcer. They } \\
\text { have been reduced to working days lost by the subtraction of one- } \\
\text { seventh. }\end{array}$} \\
\hline
\end{tabular}

the necessity of providing for the individual. Indeed, any attempt to eliminate peptic ulcer subjects from industry would result in a loss of a high proportion of the most valuable individuals, for the personality which appears to be associated with duodenal ulcer is that of the hard-working conscientious man who is particularly suited to positions of responsibility. In the industrial survey of which the above investigation formed part, it was found that duodenal ulcer was particularly common in managers and foremen (Doll and Avery Jones, to be published) and while this might, to some extent, be attributed to the special anxieties of their position, it is equally possible to explain the association on the basis of personality factors.

The ultimate aim is the prevention of peptic ulcer, but this will remain Utopian until more is known of the cause of the condition. Until then, all that can be done is to minimize the effect of ulcers by early treatment and by creating conditions in industry which will enable the peptic ulcer subject to carry on efficiently. A possible means by which this may be done is the provision of dietetic facilities in industrial canteens (Avery Jones and Newell, 1947). When this has been done it has been greatly appreciated by the employees, and although no figures are available to determine the benefits accruing, the size of the ulcer problem justifies the trial of every practical method to reduce the social and individual disability.

\section{Summary}

The sickness absence of men with proved peptic ulcers has been compared with that of men without dyspepsia, of the same age, employed in the same occupation.

In seven firms, employing 2,871 men, the mean sickness absence of men with proved peptic ulcer was 6.0 working days a year (standard error 2.75 days) more than that of the controls.

The percentage of men who had proved peptic ulcers was $5 \cdot 4$, so that the total sickness absence attributable to peptic ulcer was 32.4 working days a year per hundred men.

Early treatment and the provision of dietetic facilities in industrial canteens are the most practical steps that can be taken to reduce this loss.

Our thanks are due to Dr. F. Avery Jones, to whose interest in the subject this paper owes its origin.

\section{REFERENCES}

Avery Jones, F., and Newell, L. (1947). In " Handbook of Industria and Institutional Catering," by W. H. Emery. Baillière, Tindall and Cox. London.

Bockus, H. L. (1943). " Gastro-enterology." Saunders. Philadelphia.

Department of Health for Scotland (1939). Seventh Report on Incapacitating Sickness, 1936-37. H.M. Stationery Office. 